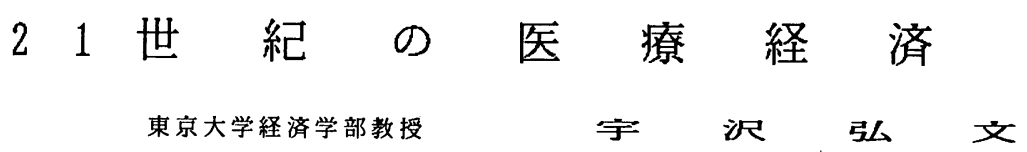

1960年代から現在にかけて、医療技術の発展には目覚 しいものがあった。それは一方で、医療の実質的内容を 著しく高度化し、大きな臨床医学的な効果をるたらすと ともに、人口構成の高年令化に伴うて医療費の急激な上 昇という経済的な影㗨をむたらした。これらの諸要因は 今後二十一世紀にかけてさらにいっそう加速化されるも のと予想され、医療技術の発展に伴う経済的ならびに社 会的なインプリケーションはますます重要な意味をすつ ようになる沓あ万う。本研究は、医療技術の発展と人口 構成の高年令化ならびに医療費の高度化との間の緊張関 係がもっとす鲜明な形で現れている終末期医療を取り上 げ、さらに一般に、将来予想される医療技術の発展に伴 って、医療資源の配分にどのような変化がおこるであろ うかということを考えてみたい。 
特 別 栈 演

21 世紀 の 医学教育

一医学と医癔の将来“雑威”-

$$
\text { 東京大 学 総 長秝亘 }
$$





\section{特別绕 演}

21 世 紀 の 福 祉

東 京大学名誉教授 社 会 保 障研 究所 顧 問

褔武

直

\section{（1）高齢社会の到来}

わが国は、1970年、65歳以上の老年人口が約 $7 \%$ とな り、高粭化 (aging) 社会の仲間入りをしました。そして 1985年現在、10\%になりましたから、15年間に 3 ポイン ト比率が高まったことになります。

ところが、今後、21世紀になるまでの15年間には、こ れまでの 2 倍に近いスピードで比重が大きくなり、16.3 \%になると予測されております。そして、21世紀になっ て 10 年あまり経過しますと、10人のうち 2 人の老人、し かも、その2人のうち1人が75葴以上の後期老年層である という、人類がこれまで経験したことのない高龄（aged） 社会が生まれ、そうした高略社会が、長期にわたって持 続するあのと推計されております。

そのような社会になりますと、現在約 7 人の生産年歯 人口で 1 人の 65 藏以上人口を支えている状況が、約 3 人 で 1 人を支えなければならぬという厳しい状況に変化し ます。わが国においては、現在、15嵅から19葴までの人 口のうち、就労しているものは約 2 割にすぎません。そ して、20歳から24荿の人口の中で、なお在学中のものが 同じく約 2 割を占めます。したがって、生産年踰人口も、 20葴から64荿とする方が実悲に即するわけですが、そう いたしますと、2.6人で 1 人を支えるということになる わけであります。

このような数字の示すところは、21世紀における日本 の社会が、きわめて厳しい社会になるということであり ます。そして、現在のわが国は、平均寿命にして男75藏 ・女81葴という世界一の長夷国になっておりますが、21 世紀になっても、この長寿を老いす若きすともに喜びあ うことができるように、いかなる社会経済的システムを 創り出すべきかが問われているということですおります。

老若ともにと申しましたのは、社会保障のシステムに おいても、青壮年が過重な負担を憤慨するようなことが おってはならないと同時に、老人が薄すぎる給付を嘆き 長命を呪詛するようなこともおるべきではないというこ とであります。

\section{（2） 21世粑の年金}

このように、老いも若きも、ともに納得できるシステ ムにしなければならないるのとして、第 1 に考えられな ければならないのは、公平な年金制度でありますが、こ の年金制度につきましては、1986年に、大改革が行われ ました。わが国の年金制度は、多くの制度に分かれてお りますが、これらを通じて共通の基礎年金が全国民をカ バーするようにし、この基礎年金にのみ国庫負担を投入 しょうという改革であり、また、すべての女性に年金権 が保障される仕組みにしようとしている点においても、
あえて大改革と称してょいかと思います。

しかし、この大改革によっても、2人半の青壮年が 1 人の老人を支えるという21世紀を展望するばあい、この 21世紀にも通用する年金制度になったとはいえません。 このたびの改革で一挙に実現できなかった給付開始年跘 の65藏への統合も、できるだけ早く実現しなければなり ませんが、被用者の年金における所得比例部分の給付額 をもう少し切り下げ、掛け金を少なくするという手直し も必要になろうかと思います。

いずれにしても、今後の公的年金は、老後生活のすべ てを保障するものとして期待されるべきものではなく、 基礎年金の水準が公的扶助の水準を下回ることも、性質 上当然であると考えなければなりません。21世紀の年金 は、世代間のバランスを考虑するばあい、生活の最低限 度を可能にする水準を最低水準とするわけにはいかない からであります。そして、年金しかなくて最低限度の生 活も成りたたぬばあい、補足給付で救うほかはないと思 います。なお、この基礎年金さえも、保険料負担ができ なくて十分には給付されない人々が、今後もかなりあり うることを考えますと、基礎年金への国庫負担を 3 分の 1 から、せめて 2 分の 1 に引き上げ、保険料の上昇をお さえられないものかと思います。

しかし、社会保障のシステムの中で、所得保障は、基 本的には、ミニマムの原則で律すべきものであり、費用 負担の優先順位は、医療保障にゆずるべきであると考え なければなりません。

\section{（3） 21世紀の医㞠}

この医療保障のシステムにおきましては、年金ほどの 抜本的な改革が行われているとはいえません。しかし、 最近、医療と保健とを統合し、各種保険集団よりの拠出 を求める老人保健制度がつくられました。分立した医療 保険間の財政調整の道が開かれたわけであります。また、 医療費の一部負担が導入され、コスト意識を高める方策 もとられております。今後も、負担の強化は免れないと ころですが、医㞠システム全体の改革も行われなければ なりません。そして、将来における医師の過剩をさける ために、医系大学の入学定員の削減も考えられるように なっております。

このように、いろいろの方策が試みられておりますが、 医療費は、年とともに增加し、高榆化の進行にともない、 いよいよ增高することが不可避であります。そして、こ の医㞠費は、年金がミニマムでよいというような意味に おいて、ミニマムを保障すれば足りるというすのではあ りません。過剩な医療は抑制しなければなりませんし、 マキシムな医療す公的な医療システムの枠外になります が、オプティマムは確保されなければなりま廿ん。 
わが国のばあい、医療費は、国民所得の約 $6 \%$ に及ん でおり、先進諸国に比して老年人口比が小さいにもかか わらず、かなりの費用を投入しているとみてよいと考え ます。国民にとって医療はきわめて接近しやすく、公的 な医療保険が十分に機能してきたといってよいと思いま す。このことが、食生活の水準の上昇とならんで、世界 一の長寿をもたらした一因でもありますが、今後は、医 療費をできるだけ抑制しながら、しかもオプティマムな 医療を確保する道を求めなければなりません。医学の進 歩が人間の幸福を增進するとは必ずしもいいきれないよ うになっている状況のもとで、オプティマムとは何かを 問うことは、きわめて困難な課題ではありますが、この 課題に解答を見出さなくては、21世紀を迎えることがで きないのであります。

そして、高齢化の進行は、寝たきりや痴呆の老人を増 加させます。それは、医療と福祉サービスが総合的に考 えられなければならないということであります。現在、 この医療と福祉サービスとの関連が論議されております が、この論議を通じて医療費の負担と福祉サービスの費 用負担のアンバランスが見直され、双方を通じる公正な 費用負担のおり方が探り出されてほしいるのだと考えて おります。

\section{（4）福祉サービスの挔充}

ところで、この福祉サーピスは、日本のばあい、先進 諸国にくらべて、著しく遅れているといわさるをえませ ん。正確な比較はできませんが、国民所得対比の比率で みるかぎり、最も多くの費用を割いているスゥェーデン の約 8 分の 1 という水準になります。

わが国では、後にふれますように、家族が老後の生活 を保障してきましたために、福祉サービスへのニードも 強くありませんでした。そして、最近まで、福祉サービ スは、低所得層対策とみられてきました。この福祉サー ビスは、特別食護老人ホームの增設にみられるように、 近年著しく搪充されてきました。しかし、年金や医療に くらべると、大きく立ち遅れているといわなければなり ません。

このような状況において、私は、年金はミニマムに、 医療はオプティマムに、そして、そこで節減された費用 によって、福祉サービスの基盤の拡大と条件の整備を急 ぐべきだと考えております。その福祉サービスは、いう までもなく、今後は、すべての階層によって求められる わけですから、負しい人には免除するにしても、利用料 を出して利用することを原則としなければなりません。 それは、貣しい人々や低所得者に対する選別的な福祉で はなく、普遍的な福祉でなければならないからでありま す。

そして私は、このような福祉サービスが、今後の高齢 社会では、ますます重要になると考えておりますが、と くに日本では、遅れているだけに、一層強調されなけれ ばなりません。

\section{（5）社会の変動と福祉サービス}

わが国においては、家業を長男が相続し、その跡とり としての長男が結婚後も同居して老親の面倒を死ぬまで みるという「家」制度が、長い間、農家や自営商工業者
において、有効に機能してきました。老後の心配は、一 般にあまりなかったのであります。ところが現在、自営 業者は少なくなり、被用者が 7 割以上になりました。上 述の「家」制度は、被用者には通用せず、崩壊せざるを えませんでした。

そして、被用者世帯が多くなり、都市化が進につれて、 老親の子らとの同居率も低下してきました。この同居率 は、20年前には80\%をこえていましたが、今や65\%にお ちております。21世紀の声を聞くときには50\%程度にな ろうかと思います。この50\%という同居率も、欧米先進 諸国の 20〜30\%にくらべると、なお高いわけですが、今 後は、同居できたとしても、同居子の妻、すなわち嫁が 老親の世話をするということは難しくなります。という のは、将来、女性の就業が一層一般化すると考えられる からであります。

現在、わが国では、被用者の37\%が女子でありますが、 一般的な就業形態は、出産青児のために退職し、䏍児期 間がすぎてから、再びパートタイマーとして働くという ことであります。そして、出産育児というハードルを越 えて終生継続的に就業したいという女性は、現在のとこ ろ、20\%以下にとどまりますが、将来、こうした女性が 徏次多くなるものと考えなければなりません。そのばあ い、仕事をやめて寝たきりの老親を介護するということ は困難になり、福祉サービスへの需要は、多くならさる をえないというわけであります。

私は、上述のような「家」制度が、わが国の福祉サー ビスの発展を遅らせたと考えるのでありますが、その立 ち遅れと、将来の需要增のゆえに、とくに福祉サーピス の拡充を重視したいのであります。

\section{（6） 21世紀の社会保障}

以上のように、21世紀の高踰社会を展望しますと、社 会保障は、総合的に考えられなければなりません。

そして、高秢化の急速な進行を前提として、年金制度 や医療制度の改革を進め、費用の抑制を図らなければな らないことは当然でありますが、とくにわが国のばあい、 福祉サービスにおいては、むしろ拡充整備されなければ ならないと考えるわけであります。

その21世紀をめざす社会保障は、このような意味にお いて、その原理を転換しなければならないというべきか もしれません。社会保障は、いうまでもなく、選別主義 から始まり、普遍主義をめさして発展してきました。そ して今日、福祉国家の危機が叫ばれ、社会保障の見直し がせまられているわけであります。このばあい、私は、 普遍主義を捨てて選別主義に後退すべきではなく、公正 な費用負担によって普遍主義を守り、同時に負担に耐え ぬ人のために選別主義を生かすほかはないと考えます。 福祉サービスに対して費用負担を求めながら拡充を図り、 負担できぬ人にも免除によって利用を保障するというこ とが、普遍主義と選別主義の両立の例証であるというわ けであります。 


\author{
I wao M. Mori yama, \\ Executive Director, \\ International Institute for Vital \\ Registration and $S t a t i s t i c s$ \\ Bethesda, Maryland, U.S. A.
}

The next century will undoubtedly bring about many important discoveries and development in various fields of endeavor. Many of them will impinge on the health and welfare of the world population. Also, there are possibilities that the environment around us might change. Some, like the nuclear winter and the greenhouse effect could be catastrophic in nature.

The varming trend of the earth's temperature, or the so-called "greenhouse effect" is a potential problem which has been under study but has not yet been addressed seriously in terms of action. At the present rate of warming, significant climatic changes will be experienced in the next century. Substitutes for fossil fuel, the major source of the problem, will have to be introduced. Because there is some question about the reversibility of the greenhouse effect, action needed to prevent further buildup of carbon dioxide in the earth's atmosphere cannot be delayed too long.

Another atmospheric pollution problem is the erosion of the ozone layer through the chemical reaction with chlorofluorocarbons(CFC) released into the atmosphere. Although a satisfactory substitute has yet to be found for CFC, the industrialized countries have agreed just this year to gradually eliminate the use of CFC as solvents and refrigerants. Without the protection of the ozone layer, a large increase in the incidence of skin cancer may be expected.

Although the consequences of environmental pollution can be serious, they are preventable to the extent that man is willing to pay the price for a clean environment.

With economic development, there will be a worldwide improvement in health. The elimination of parasitic diseases like malaria, schistosomiases, and filariasis will greatly improve the health and productivity of many Third World countries.

The reduction in the death rates for the infective and parasitic diseases in the developing countries will be accompanied by increases in the death rate for the chronic diseases, namely, cardiovascular renal diseases and cancer. The health status of many of the Third World countries will become more like that of the present day industrial countries. However, infant and child health will probably remain a significant problem in the next century in subsaharan Africa and in some of the Asian countries.

What the future will bring in terms of exotic and unusual diseases like AIDS is difficult to tell. However, all the present advances in medical research point towards production of new or improved vaccines, improved diagnostic methods, a better understanding of etiology of disease, and new therapeutic procedures. All of this will contribute to a longer life for the world population.

It is fairly clear that the world population will continue to age for many more years to come. Not only will there be more elderly people, there will be more people in the very old ages. Also, because females outlive the males, there will be an increasing number of elderly women as compared with men. This will have important social and economic implications.

The health concerns in the next century will be geriatric in nature. In addition to coping with the chronic diseases of today, increasing numbers of osteoporosis, hip fractures, arthritis, urinary incontinence and visual and hearing impairments may be expected. Many more will be afflicted with Alzheimer's disease and related dementia. These are some of the problems that diminish the quality of life in old age.

The problems of the aged will impose a serious burden on the medical and nursing care personnel and facilities of the various countries. Unless there is a significant increase in the fertility of the world population, the cost of medical care of the aged will fall on a proportionately smaller population in the productive ages. In many countries, it is questionable if the financial resources and manpower can increase proportionately to meet this rising load. Serious study needs to be given to the care of the elderly and 
how such care can be provided in an affordable manner. Also, greater effort will have to be made to keep the aged well as long as possible so that they can operate without limitations up to the last moment. 


\section{1 世紀 の疾 病 - 死亡構造}

雄

\section{1) はじめに}

我が国の明治以来の、社会・経済・文化などの歴史の 全般的な発展は極めて著しいるのがあり、それらを受け て我が国の疾病・死亡構造の变遷も、極めて目まぐるし いものがあった。まず、多くの急性伝染病により多数の 人々が苦しみ、その命が奪われていった。次いで、結核 症など慢性感染症によって極めて多数の、とくに若者が 苦しみ、死んでいった。第二次世界大戦は我が国の多く の都市を焦土と化したが、我が国民にも消化性湞鹗によ る死亡危険を、当時成人であった人々に生年群順にその 後現在まで継続する、ほぼ一定の死亡率の形で課したの である。そして、我が国の戦後の発展は世界史的事象と 呼ばれるほど急激なるのであった。

このように、我が国の発展の歩みはあまりにも急でか つ激しかったため、それらの变化がその各時点での生存 者に強く影翠した。このために我が国に現存し、今後も 生存してゆく人々には、生年群別に疾病・死亡構造の各 種の指標に関して各種の特徵が見られることとなったの である。

\section{2）我が国民に課せられている疾病・死亡椿造の履歴 \\ (1) 消化性謴瘍}

我が国の男女の消化性潰富の総死亡率は、1947年に高 いピークを示している[人口10万対死亡率男 : 12.6(1910) $\rightarrow 49.7(1952) \rightarrow 4.1(1985)$ 、女: 8.0(1910) $\rightarrow 17.4(1947)$ $\rightarrow 3.4(1985)]$ 。第二次世界大戦に参加したアメリカを除 く多くの国々で、この年にビークが見られている。1947 年の 5 嵅ごとの年齢階級別に死亡率の推移を検討すると、 20葴以上65葴未満では 5 嵅ごとにほぼ1.3〜1.8倍の死亡 率を示しているが、その後、戦後生れた生年群を含む、 ほぼ全ての 5 葴ごと生年群で1947年の死亡率をやや下回 る数字を示したまま現在に至っているのである。これは 女です認められた。要するに、戦後の生年群ごとの消化 性潰瘍死亡率は、加粼にともなって上昇することもなく、 また、ほとんど変化することもないのである。Susser は、これとほぼ同様の事象を、ドイッ空軍による爆故を 受けていたロンドン市民に見出し「コホート現象」と名 づけた。

（2）腎炎・ネフローゼおよびネフローゼ症侯群

消化性溑瘍とほぼ類似の動向は腎炎・ネフローゼおよ びネフローゼ症侯群の死亡率にも見られている。ただし、 この現象は1975年には終局を迎えつつあったもののごと くである。1980年にはやや变形した形となり 1916-1920 年生れ以降の生年群では、後加生れた生年群ほど、低 くなる傾向を示している。

\section{3）コホート現象による疾病の分類}

若年首を除くと、集団の年路階級別死亡率は片対数グ
ラフ上でほぼ直線を形成することが多い。この直線は Gompert $\mathrm{z}$ 直線とも呼ばれる。この直線の变化は、大き く分けて、

(1)下方への移動、

(2)上方への移動、

(3)おる点を中心として反時計方向への回転、

(4)おる点を中心としての時計方向への回転、

(5)年野階級にかかわらずほぼ等しい死亡率を示していた ちのが、ほぼ全年踰階級で增加した場合、

(6)変化の全く認められない場合、

の 6 つに分けられる。我が国の1900年から1980年までの 総死亡および主要疾患についての Gompert $\mathrm{z}$ 直線の变化 では(4)の変化は認められなかった。また、(6)の例は男で は犊頭の悪性新生物など、女では肝硬变などに認められ、 舌の悪性新生物、不虑の事故および自殺では男女に認め られた。(1)ないし(3)および(5)の変化を示したものでは、 いずれす、コホート現象が認められた。男女の紛死亡に も(1)の変化が認められた。

\section{4 ）成人生命表による 21 世紀初頭の性別の人口、給死} 亡数および主要死因別死亡数の推测

同時に生れた10万人の生涯の死亡記録があれば、世代 生命表を作ることが可能となる。ある生年群の同様の記 録があれば、コホート生命表を作ることが可能となる。 我が国の記録は、5 年ごとでは、1920年から1940年まで と1950年以後のみであるので、コホート生命表はまだ得 られない。しかし、1950年以後の生年群別年酮階級別死 亡事および平均余命はこれまでの死亡率の推移から推測 できるが、これは現存する男女の成人のものなので、わ れわれはこれを成人生命表と呼んだ。これが得られれば、 現存する男女に関しては、人口などの予測が可能となる。 これに基づくと、2000年以後の人口、総死亡率、主要疾 患別死亡率を推測できることなる。

\section{5 ）患者数および受療率と有病率}

戦後の我が国の衙生統計の分野には、世界的に全くュ ニークな指標が残されている。受療率と有病率である。 これらは我が国の独自な指標であるために、国際的比較 は不可能である。しかし、我が国の 21 世紀の疾病構造 を検封するにはきわめて重要な指標である。

\section{(1) 受療率}

医療機関を訪ねる場合に、多くの人々がまず心配した ちのの一つは医療の貫用であろう。1922年に健康保険法 が施行されたが、その恩恵はきわめて限られた人々にの み与えられた。1957年から1961年にかけて、我が国では、 国民皆 (医療) 保険制度がすすめられ、完成されてゅくの であるが、これによって、国民の医療行動に大きな変化

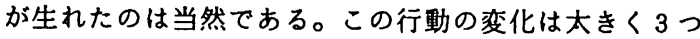


の時期に分けて観察された。1955年から1961年までと、 1961から1970年まで、さらにそれ以後である。いずれる、 上述した Gompertz 直線の変化の(3)であり、その回転の 中心が各時期に対伈して、段階的に、高年秢の方向に移 動したのでおる。この結果、最近では、若年粭屏の受療 率は低下し、高年路のそれは大きく増加した。疾病大分 類別に、受療率の年次別の推移を検討すると、筋骨格系 および結合組織の疾患と循䍗系疾患の伸びが大きく、前 者は特に、近い将来に1955年の10倍に到達する勢である。 その他、血液および造血器の疾患、新生物、呼吸器系の 疾患、消化系の疾患などが1955年の 2 ないし 4 倍となっ ている。地域ブロック別に年齢階級別受療率を検討する と、大きな地域差があることが認められた。中国四国ブ ロックが全年秢階級で最も高く、関東ブロックが最も低 かった。賃病大分類別には、中国四国ブロックでは呼吸 系の疾患がやや低いものの、その他の全ての疾患群で高 い受療率が認められた。人口規模別に検討すると、大都 市では、消化系の疾患、循㻴系の受療率が高いことが認 められた。

\section{(3)有病率}

国民健康調查で得られた有病率はPrevalence ではな い。有病率も受療率におくれて、ほぼ同様の、高龄者の 伸びを中心とする推移を示しだ。有病率と動物性蛋白質 摄取量（国民栄養調查）との間には1955年以降年次別に、 動物性蛋白質摄取量が増加するにしたがって、有病率が 增加するという直線的関係が認められた。

(3)有病率、受療率と死亡率

1891-1900年生れの生年群では、1955年、1965年およ び1975年に有病率と受癔率および死亡率の記録が得られ ているが、各比率を人口10万対にして片対数グラフ(綐 軸＝各比率、横軸＝年次) 上で検討すると、いずれるほ ぼ直線的な推移を示し、しかも、互にほぼ平行となる。 したがって、この期間では、この年制階級について、

(有病率) : (受療率) : (死亡率) $=3650: 730: 1$ であることが認められたが、これはこの生年群にのみ観 察された、かなり低い推測値であると考えられる。

受療率(綎軸) と死亡率 (横軸)を年格階級別に両対数グ ラフ上にとり1955年以後の年次別変化を検討すると、1524嵅の年齢階級では、たとえば時計の面上で表現すると、 (1) 3 時の位置から反時計方向に12時の位置に移動し、 (2)さらに、9 時の位置に移動し、

(3)その後、時計から離れて、左の方向に移動している。

すなわち、受療率は1965年ごろまで増加しており、そ の後、1955年のレベルにもどる。そして、その後はぼそ のレベルを維持するが、死亡率は観察期間中ずっと減少 を続けるのである。この年略階級に見られた事実は、そ れ以下の年塗階級およびそれより上の年路階級では、そ の途中経過までが認められるに過ぎない。特に、65-74 墄および75葴以上の年齢階級では、受療率はまだ12時の 位置にも至ってはいない。今後もなお受療率の増加が考 えられ、21世紀にも、問題が残ると考えられる。

疾病大分類別に、年踌階級別の受療率と死亡率の 1955 年以後の推移を検討すると、大きく 4 つに分類すること が可能でおった（ただし、妊娠分婏、先天異常、周産期 の疾患などの群は検討していない）。
(1)高年齢ほど受療率も死亡率も高くなるという傾向が明 らかで、ほぼ全年椧階級の受療率と死亡率の両者とも高 くなる推移が見られた疾患。21 世紀に最も問題となる と思われる疾患二新生物。

(2)ほぼ全年秢階級で死亡率の減少の傾向が見られるもの の、高年格ほど受療率も死亡率も高くなるという推移が 明らかで、しかし、受療率はとくに高年粭層で大幅な上 昇を続ける疾患。今後も受療率の大幅な上昇が予測され る疾患=筋肉骨格系および結合組織の疾患。

(3)高年齢ほど受療率も死亡率も高くなるという推移が明 らかで、80藏以上の年紫階級の受療率を除き、ほぼ全年 齢階級で死亡率す受療率も減少に転じた疾患。2 1 世紀 には、徐々に死亡率と受療率の減少が予測される疾患= 循㻴系の疾患、神経系および感覚器の疾患、内分泌、栄 養代謝疾患ならびに免疫障害、損傷および中毒。

(4)ほぼ全年舲階級で死亡率の減少の推移が見られるもの の、高年竛ほど死亡率が高くなるという推移が明らかで あるが、受療率は全年制階級でほぼ同様の值を示して推 移しているもの。今後、死亡率の低下は期待できるが、 受療率は大幅な伸びを示すことなく現在とほぼ同様の値 で推移すると予测される疾患＝感染症、血液および造血 器の疾患、呼吸系の疾患、消化系の疾患、泌尿生殖系の 疾患、皮唐および皮下組織の疾患、精神障害など。

傷病大分類別に、受療率と有病率の関係の年次推移を 検討すると、各疾患群別に、受療率の伸びの鈍化と有病 率の大きな伸びが認められた。多くの疾患群で、有病率 は今後なお大きく伸びることが予測される。

\section{6 ）医療機関および医療従事者}

精神病院数は1955年 (260) から急增し、1982年 (997)に は約 4 倍となっている。同じ期間に一般病院は4096から 8340 と約 2 倍となっている。この間に伝染病院 $(73 \rightarrow 17)$ および結核療養所 $(676 \rightarrow 33)$ は大きく減少している。病 床数は、やはり、1955年から大きく增加して総数約 132 万、一般病床約 90 万、精神病床的 31 万となっている。

現在、医師数は増加中であるが、1955年からの急激な 受療渪の增加のために、1960年から1969年までの期間、 一日あたり(患者総数/医師数)はほぼ直線的に伸び、約 45から65(1973年)となっている。我が国の人口は約 1.2 億(1984年)、受㞠率人口10万対6403(1984年)、患者数䄪 770 万人 $(1984$ 年 $=1$ 日おたり)、医師数約 18 万人である。 医師一人あたり約 43 人の患者を診察していることとなる。

\section{7 ）医噔費}

国民総生産に占める国民医療費は約2.7\%(1955年)から 約4.9\%(1979年)となったが、1954年から1971年までは、 この比率の伸びにしたがって大きな死亡率の隇少と大き な平均余命の延辰 (女: $Y=8.02 X+47.92$, $Y:$ 平均余命, $X:$ 比率 \%, 相関係数 $=0.8947)$ が認められたが、1971年 以後はこの比率の伸びにしたがって、より少ない死亡率 の減少とより少ない平均余命の延長 (女: $Y=1.81 \mathrm{X}+$ 69.54， $\mathrm{Y}$ :平均余命， $\mathrm{X}$ : 比率 $\%$, 相関係数 $=0.9657$, 1979年まで)が認められた。この比が $8 \%$ となった場合 の総死亡率は人口 10 万対 509.6 と推測され、女の平均余 命は 87.48 藏と推測される。 